\title{
Upaya Guru dalam Meningkatkan Kemampuan Motorik Halus Anak Usia 5-6 Tahun Melalui Kegiatan Kontruksi 3 Dimensi dari Barang Bekas Secara Daring di Pos PAUD
}

\author{
Zahrotun komariah", Huriah Rachmah \\ Prodi Pendidikan Guru PAUD, Fakultas Tarbiyah dan Keguruan, Universitas \\ Islam Bandung, Indonesia.
}

*Zahramartz040503@yahoo.co.id,_huriahrachmah@gmail.com

\begin{abstract}
Seeing the fine motor skills of children aged 5-6 years at the PAUD post who have not been able to use stationery and cutlery properly, cut according to patterns, pasted pictures appropriately, so that children are less able to carry out daily skills such as buttoning clothes, tying shoelaces, pouring water and others. The research conducted was a case study qualitative research, the subjects of this study were 18 children in group B. Data collection techniques through interviews and observation of documents and children's work done online. The results showed an increase in the child's fine motor skills after the teacher gave coloring, cutting and pasting activities. This can be seen from the number of children who have developed very well in aspects of fine motor development. The teacher's implementation planning and assessment are already good, the use of used goods for activities already exists but is not yet diverse. The construction of 3-dimensional works is not much because there are not many ideas in making 3-dimensional works.
\end{abstract}

Keywords: Interaction, Collaboration, and Role Play.

\begin{abstract}
Abstrak. Melihat adanya kemampuan motorik halus anak usia 5-6 tahun di pos PAUD yang belum dapat menggunakan alat tulis dan alat makan dengan benar, menggunting sesuai dengan pola, menempel gambar dengan tepat, sehingga anak kurang mampu dalam melaksanakan keterampilan sehari-hari seperti mengancing baju, mengikat tali sepatu, menuang air dan lain-lain. Penelitian yang dilakukan adalah penelitian kualitatif studi kasus, subjek penelitian ini adalah anak-anak di kelompok B sebanyak 18 anak. teknik pengumpulan data melalui wawancara dan observasi dokumen dan hasil karya anak yang dilakukan secara daring. Hasil penelitian menunjukkan adanya peningkatan kemampuan motorik halus anak setelah guru memberikan kegiatan mewarnai menggunting dan menempel. Ini terlihat dari banyaknya anak yang memiliki nilai berkembang sangat baik pada aspek-aspek perkembangan motorik halus. Perencanaan pelaksaan dan penilaian yang guru lakukan sudah baik, penggunaan barang bekas untuk kegiatan sudah ada namun belum beragam. Kontruksi hasil karya 3 dimensi belum banyak karena belum banyaknya ide dalam membuat hasil karya kontruksi 3 dimensi.
\end{abstract}

Kata Kunci: motorik halus, kegiatan mewarnai menggunting dan menempel, barang bekas. 


\section{A. Pendahuluan}

Anak diawal kelahiran hingga 6 tahun adalah masa-masa yang sangat pesat pertumbuhan dan perkembangannya. Pertumbuhan dan perkembangan adalah perubahan yang terjadi pada anak baik itu secara jasmani (fisik) dan rohani (jiwa), menurut Hurlock, perkembangan adalah rangkaian perubahan bertingkat yang terjadi dari proses kematangan dan pengalaman sedangkan pertumbuhan menurut Khodijah (2016: 35) adalah perubahan yang terjadi pada fisik yang dihasilkan dari proses matangnya fungsi fisik secara normal anak dalam waktu tertentu. Usia 0-5 tahun anak akan mengalami pertumbuhan dan perkembangan yang meningkat dengan pesat.

Tumbuh kembang anak perlu dipantau dari berbagai aspek, baik fisik, psikologis dan sosial. Pemantauan pertumbuhan dan perkembangan anak dilakukan secara terus menerus dan dilakukan oleh orang tua bersama sekolah atau posyandu di lingkungannya. Pemantauan yang disarankan adalah usia 0-1 tahun setiap bulan , usia 1-3 tahun setiap 3 bulan, usia 3-6 tahun setiap 6 bulan, dan di tahun berikutnya setahun sekali.

Dalam Permendikbud No. 137 Tahun 2014 pasal 4, pendidikan anak usia dini bertujuan untuk melakukan stimulasi dalam membantu pertumbuhan dan perkembangan jasmani dan rohani anak sesuai dengan tingkat capaian perkembangan, membantu mengoptimalkan perkembangan anak secara keseluruhan dan terintegrasi dalam semua aspek perkembangan serta membantu membentuk sikap, pengetahuan dan keterampilan anak.

Dalam Permendikbud nomor 137 tahun 2014, perkembangan anak mencakup 6 aspek yaitu moral dan agama, sosial-emosi, bahasa, kognitif, motorik dan seni. Perkembangan moralagama berhubungan dengan perilaku anak yang berkaitan dengan agama yang dianutnya dalam hal ini mengikuti agama yang dianut orang tuanya, perkembangan sosial-emosi berhubungan dengan cara perilaku anak berdasarkan norma yang ada di masyarakat. Perkembangan bahasa berhubungan dengan cara anak berkomunikasi secara lisan dengan lingkungannya, perkembangan kognitif berhubungan dengan kemampuan berpikir anak dalam mengerti sesuatu. Perkembangan seni berhubungan dengan cara anak mengungkapkan keindahan yang dirasakannya.

Menurut teori sistem dinamik yang dikemukakan oleh Esther Thelen, ketika bayi bertindak dan membentuk persepsi merupakan hasil dari keterampilan motorik.Menurut Bertenthal, untuk mengembangkan keterampilan motorik, pertama-tama bayi harus membentuk persepsi mengenai sesuatu di sekitarnya hingga memotivasi dirinya untuk bertindak dan menggunakan persepsinya ntuk memperhalus gerakannya. Perkembangan motorik merupakan proses aktif yang mengembangkan keterampilan anak dari waktu ke waktu.

Perkembangan motorik terbagi atas dua yaitu motorik kasar dan motorik halus. Menurut Susanto dalam Jurnal pesona PAUD, motorik halus adalah gerakan halus yang melibatkan bagian yang dilakukan oleh otot-otot kecil dan tidak memerlukan tenaga. Namun gerakan halus ini memerlukan koordinasi.(Indraswari, vol.1.No.1:3)

Berdasarkan pengamatan yang dilakukan pada tanggal 20 Juli tahun 2020 di kelas usia 5-6 tahun kelompok B Pos PAUD ditemukan permasalahan yang berkaitan dengan motorik halus seperti menggenggam crayon saat kegiatan mewarnai, belum dapat menggerakan gunting dengan benar, serta belum dapat menggunting mengikuti pola.

Kegiatan mengembangkan motorik halus dilakukan dengan prinsip-prinsip pembelajaran anak usia dini yaitu belajar adalah bermain, bermain adalah belajar. Dimana kegiatan yang dikemas dengan bermain akan menyenangkan bagi anak. Serta dibuat menarik, karena kegiatan yang menarik akan mendorong anak untuk selalu aktif mengikuti kegiatan.

Kegiatan pembelajaran yang menarik serta menyenangkan dapat dilakukan dengan bermacam metode. Metode yang sering digunakan guru PAUD diantaranya bercerita, bernyanyi, bercakap-cakap, bermain peran, sosiodrama, pemberian tugas, demonstrasi/peragaan, eksperimen sederhana, karya wisata dan proyek (Masnipal, 2018:104). Pada kegiatan pemberian tugas atau proyek anak dapat diberikan kegiatan mewarnai, menggunting, menempel, meremas dan melipat.

Mewarnai, menggunting menempel $(3 \mathrm{M})$ dan melipat merupakan kegiatan yang berkaitan dengan kemampuan menggunakan alat untuk melatih motorik halus anak. Motorik halus anak akan menjadi dasar kemampuan yang berkaitan dengan ketelitian berkarya saat anak 
dewasa, serta mudah dan cepat tanggap dengan apa yang terjadi di lingkungannya yang melahirkan keterampilan menyesuaikan diri. Kegiatan mewarnai, menggunting dan menempel dapat terintegrasi dalam metode pembelajaran. Kegiatan mewarnai, menggunting dan menempel (3M) agar menyenangkan bagi anak diberikan dengan bermacam-macam media.

Hasil penelitian yang sudah dilakukan dengan kegiatan mewarnai, menggunting dan menempel $(3 \mathrm{M})$ menggunakan metode proyek, metode demostrasi dan pemberian tugas. Menyimpulkan bahwa peningkatan motorik halus sangat dipengaruhi oleh penerapan metode yang tepat, efektif dan menarik. Serta menciptakan suasana ruang belajar yang menyenangkan dimana anak merasa senang dan termotivasi untuk belajar. Penggunaan alat peraga juga menjadikan anak antusias, senang, dan tidak mudah menyerah selama melakukan kegiatan. Agar anak dapat mengaktualisasikan diri dalam proses pembelajaran perlu pemberian ruang gerak dan waktu yang seluas-luasnya, sehingga memperlihatkan adanya peningkatan perkembangan motorik halus dengan merangsang anak untuk melakukan kegiatan mewarnai, menggunting dan menempel (3M) dengan senang.

Dengan menggunakan media barang bekas dan kontruksi 3 dimensi, akan menumbuhkan kreativitas guru dan juga anak. Pengunaan barang bekas juga akan mengurangi biaya karena menggunakan barang bekas seperti dus bekas, gulungan benang bekas, CD bekas yang dikumpulkan oleh guru atau pun dibawa anak dari rumah dapat menjadi media mewarnai, menggunting dan menempel.

Berdasarkan hasil penelitian terdahulu, observasi awal dan urgensi penelitian maka peneliti memilih judul "Upaya Guru Dalam Meningkatkan Kemampuan Motorik Halus Anak Usia 5-6 Tahun Melalui Kegiatan Kontruksi 3 Dimensi Dari Barang Bekas Secara Daring Di POS PAUD". Tujuan penelitian secara khusus adalah untuk mengetahui kemampuan motorik halus anak usia 5-6 tahun, untuk mengetahui perencanaan kegiatan mewarnai menggunting dan menempel dalam meningkatkan perkembangan motorik halus anak, untuk mengetahui pelaksanaan kegiatan mewarnai menggunting dan menempel dalam meningkatkan perkembangan motorik halus anak, untuk mengetahui evaluasi dalam meningkatkan kemampuan motorik halus anak dengan melalui kegiatan mewarnai menggunting dan menempel, untuk mengetahui hambatan-hambatan dalam pelaksanaan kegiatan mewarnai, menggunting dan menempel.

\section{B. Landasan Teori}

Dalam Islam menuntut ilmu merupakan hal yang paling tinggi sehingga ini menjadi penting dan wajib. Seorang penuntut ilmu tidak akan memperoleh manfaat dari ilmu itu jika tidak menghomati dan memuliakan guru, guru sangat dihargai kedudukannya.

Peranan guru sangat penting bagi kemajuan bangsa, merekalah yang bertanggung jawab membangun generasi bangsa. Guru bukan hanya memberikan ilmu tapi juga pendidikan keimanan dan ahlak atau perilaku. Dalam Islam seorang guru haruslah bertanggung jawab mendidik manusia menjadi generasi muslim yang beriman dan beramal shaleh serta mampu melaksanakan tugas terhadap dirinya sendiri, masyarakat, maupun negara.

Peran guru PAUD bagi anak hanya sebagai mentor atau fasilitator, bukan hanya sekedar

mentranser. Sehingga guru dapat mengerti bagaimana cara berpikir anak, untuk mengembangkan serta menghargai pengalaman anak untuk itu guru dapat menggunakan berbagai metode belajar yang memungkinkan anak aktif.

Menurut Hurlock (2016:2) perkembangan adalah proses kematangan dan pengalaman yang mengakibatkan perubahan bertingkat. Perkembangan adalah perubahan peningkatan kemampuan seseorang, berbagai perubahan dalam perkembangan bertujuan agar individu dapat menyesuaikan diri dengan lingkungan tempat tinggalnya.

Menurut Hildayani, dkk (2015:3.6) gerakan motorik halus yaitu gerakan terbatas yang meliputi otot kecil, terutama di bagian-jari-jari. Menurut Sujiono gerakan motorik halus tidak terlalu membutuhkan tenaga, namun membutuhkan koordinasi mata dan tangan yang cermat. Gerakan motorik halus membuat anak dapat berkreasi seperti menggunting kertas, menggambar sederhana dan mewarnai, menjahit dan menganyam. Dalam melakukan gerakan motorik halus memerlukan keterampilan fisik serta kematangan mental. 
Kegiatan yang dapat dilakukan untuk meningkatkan kemampuan motorik halus anak berhubungan dengan penggunaan tangan, yaitu koordinasi antara tangan dan mata. Salah satu kegiatan yang dapat dilakukan adalah mewarnai gambar dengan crayon atau pensil warna, menggunting dan menempel, mewarnai gambar dengan menempelkan potongan kertas kecil.

Membubuhkan warna pada berbagai media merupakan kegiatan yang disukai anak, baik itu dilakukan dengan menggambar atau meletakkan warna media yang harus diwarnai. Kegiatan menggunting sangat berguna bagi anak untuk melatih menggunakan alat dan keterampilan memotong objek. Menempel biasanya dilakukan setelah kegiatan menggunting.

menempel gambar atau benda dilakukan pada tempat yang telah disediakan dengan garis pinggiran untuk membatasi objek. Dalam menempel sebaiknya tidak menggunakan lem yang berair atau encer sekali agar tidak menjadikan potongan gambar mudah kusut.

Barang sisa dan tidak dipakai lagi dapat dikatakan barang bekas. Barang bekas mudah kita temui di sekeliling kita seperti koran, majalah, dua, kaleng, botol, kain, plastik dan lain sebagainya. Selain mudah ditemukan, barang bekas ini pun murah harganya. Namun penggunaan barang bekas dalam kegiatan anak akan menambah kreativitas guru dan juga anak didik.

\section{Hasil dan Pembahasan}

Metode penelitian yang dilakukan dengan pendekatan kualitatif, menggunakan metode studi kasus, penelitian kualitatif dapat digunakan untuk mengungkapkan dan memahami sesuatu dibalik fenomena yang belum diketahui sedikit pun, atau dapat digunakan untuk mendapatkan wawasan tentang sesuatu yang baru sedikit diketahui.

Berdasarkan hasil wawancara peneliti dengan guru di POS PAUD yang mengajar di kelas kelompok B usia 5-6 tahun. Guru dapat mengetahui perkembangan motorik halus anak ketika anak dapat mengelem dengan rapih, tidak belepotan. Anak dapat menggunting dengan rapih. Hal yang dapat mendukung perkembangan motorik halus anak menurut guru adalah ketelatenan anak mengerjakan tugas dan dapat mengerjakan tugas yang diberikan guru tepat waktu. Gerakan yang menggunakan motorik halus menurut guru saat anak melakukan kegiatan menempel, menggunting, mewarnai, menebalkan huruf dan meremas.

Menurut guru tujuan dari pengembangan motorik halus anak adalah agar anak lebih sabar. Metode atau cara pembelajaran yang dilakukan guru dengan cara bermain, sehingga anak menyukai kegiatan yang diberikan.

Sebelum kegiatan pembelajaran dimulai guru membuat perencanaan belajar baik itu mingguan maupun harian, perencanaan ini di sebut RPPM (Rencana Pelaksaan Pembelajaran Mingguan) dan RPPH (Rencana Pelaksanaan Pembelajaran Harian). RPPM dan RPPH ini dibuat oleh guru setiap hari jumat, untuk kegiatan minggu depan. RPPM dan RPPH ini dibuat dengan menggunakan standar perkembangan sesuai dengan kurikulum, kurikulum yang digunakan oleh sekolah adalah standar yang diberikan oleh pemerintah yaitu kurikulum tahun 2013 atau sering disebut kurtilas. Perencanaan kegiatan pembelajaran sangat penting peranannya dalam menentukan apa saja yang akan dilakukan saat kegiatan pembelajaran. Perencanaan kegiatan pembelajaran di Pos PAUD sudah baik dan lengkap, dimana guru wajib membuat perencanaan pembelajaran, perencanaan ini berupa RPPM dan RPPH. RPPM dan RPPH ini dibuat sesuai tema yang sedang dipelajari dan standar pencapaian perkembangan anak, standar penilaian ini sesuai dengan yang tercantum dalam kurikulum 13. Dalam program mingguan (RPPM) terdiri dari identitas program, tujuan pembelajaran, materi pelajaran yang disesuaikan dengan tema pembelajaran. Dari program mingguan guru akan menurunkannya menjadi program harian (RPPH) didalamnya terdiri dari identitas program, tujuan pembelajaran, materi pembelajaran, sumber belajar, metode pembelajaran, alat dan bahan yang digunakan. Sebelum kegiatan dimulai guru menyediakan bahan-bahan atau media yang akan digunakan saat pembelajaran. Media yang digunakan sesuai dengan tema yang sedang dipelajari. Media yang digunakan disediakan oleh sekolah. Jika di sekolah tidak ada, maka guru akan membawa dari rumah. Atau membelinya dengan menggunakan uang dari sekolah. Untuk media yang menggunakan barang bekas, guru tidak perlu membelinya. Barang bekas ini biasanya didapat dari tetangga sekitar sekolah atau siswa membawa dari rumah.

Dengan adanya pandemi covid-19 pembelajaran tatap muka ditiadakan, dan 
menggantinya dengan belajar dari rumah secara daring. Perencanaan belajar secara daring dilakukan oleh Pos PAUD dengan membuat video kegiatan untuk dikirimkan kepada orang tua. Dalam video ini guru mencontohkan langkah-langkah mengerjakan tugas yang akan mereka kerjakan.

Dari hasil wawancara dengan guru dan orang tua, guru menggunakan media saat kegiatan disesuaikan dengan tema, guru kadang menggunakan media yang sudah jadi atau membuat sendiri. Saat kegiatan pembelajaran yang menggunakan barang bekas, guru menyediakan bahan yang didapat dari tetangga atau siswa. Kegiatannya pun disesuaikan dengan tema. Orang tua selama kegiatan belajar dari rumah mendapatkan media kegiatan yang sudah disediakan guru, setiap hari Senin guru wajib menyiapkan media atau bahan kegiatan selama seminggu. Orang tua mengambil media yang sudah disiapkan ke sekolah. Barang yang digunakan sebagaian menggunakan barang bekas Sebagian menggunakan barang baru. Setiap minggu guru memberikan informasi kepada orang tua tentang tema yang sedang dipelajari anakanak.

Peranan guru di sekolah sebagai pembimbing saat anak-anak mengerjakan kegiatan. Bimbingan ini diberikan sejak awal pembelajaran, saat pembelajaran dan akhir pembelajaran. Saat ini peranan pembimbing dilakukan oleh orang tua, karena kegiatan belajar dari rumah. Saat kegiatan belajar dari rumah masih peranan orang tua mengarahkan dan membimbing anak mengerjakan tugasnya.

Dari hasil observasi peneliti, guru memberikan contoh kegiatan yang akan dilakukan oleh anak. Media kegiatan yang digunakan dari barang bekas dan baru, dari hasil karya terlihat kemampuan motorik halus anak saat mewarnai yang berhubungan dengan koordinasi mata dan tangan. Kemampuan menggunting, anak belum dapat menggunting mengikuti pola. Dan menempel, belum dapat menempel dengan tepat.

Dengan proses pembelajaran dari rumah ini memaksa sekolah-sekolah untuk melaksanakan pembelajaran jarak jauh (PJJ) atau daring, yang sekarang menggunakan istilah belajar dari rumah (BDR). Guru mengirimkan video kegiatan kepada orang tua melalui whatsapp, setelah mendapatkan video kegiatan dari guru, anak-anak akan mengerjakan tugas yang diberikan dari rumah dengan pengawasan orang tua atau orang dewasa lain yang ada di rumah. Selama anak mengerjakan tugas, orang tua mendokumentasikannya berupa foto atau video. Kemudian dikirim kepada guru melalui WA (Whatsapp). Untuk itu orang tua dan guru harus mempunyai kuota internet agar proses belajar daring dapat terlaksana. Guru menyiapkan media pembelajaran untuk 1 minggu untuk setiap anak, yang akan orang tua ambil di hari Senin setiap minggunya.

Dalam format lembar penilaian harian berisi identitas kelas atau kelompok usia, tanggal penilaian, aspek dan indikator perkembangan anak sesuai kurikulum 13. Penilaian ini di isi oleh guru kelas dan diketahui oleh kepala sekolah.

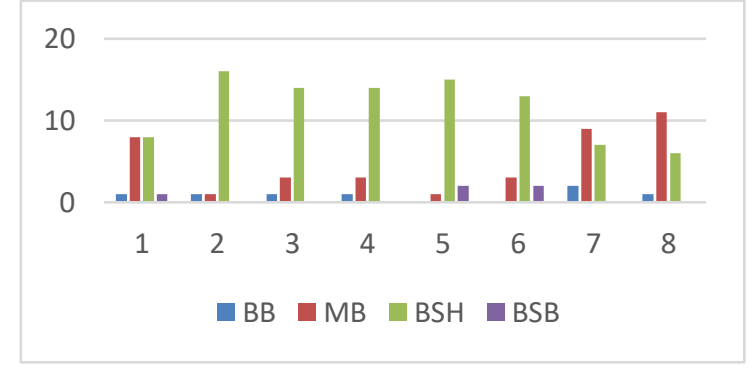

Gambar 1. Grafik Motorik Halus Anak Sebelum Kegiatan 


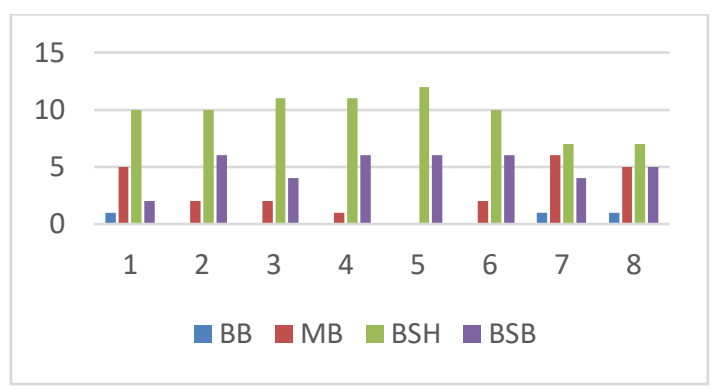

Gambar 2. Grafik Motorik Halus Anak Setelah Kegiatan

Guru melakukan penilaian yang dilakukan setiap hari dengan mengisi format penilaian harian, penilaian diisi berdasarkan kegiatan yang anak lakukan, sejak anak mulai melakukan kegiatan hingga akhir. Selanjutnya yang dilakukan guru melakukan penilaian hasil karya. Setelah penilaian harian, ada penilaian bulanan yang merupakan rekapan dari penilaian harian. Selama kegiatan BDR, guru mengalami kesulitan dalam melakukan penilaian karena tidak dapat melihat proses secara langsung. Untuk itu guru di Pos PAUD melakukan beberapa strategi agar dapat membuat laporan perkembangan anak. strategi tersebut adalah gabungan penugasan, home visit dan laporan kegiatan harian. Penilaian untuk penugasan dilakukan harian oleh guru saat orang tua mengirimkan foto atau video kegiatan. Dari hasil kegiatan penugasan yang dikumpulkan setiap minggu guru dapat menilai kemampuan anak, namun penilaian tersebut belum bersifat akhir karena ada penilaian tambahan dari home visit. Penilaian yang didapatkan kemudian dikumpulkan dan di analisis untuk melihat perkembangan anak.

Dari grafik motorik halus sebelum dan sesudah kegiatan, terlihat peningkatan motorik halus anak sebelum dan sesudah pelaksanaan kegiatan. Pada grafik pertama perkembangan motorik halus anak yang berkembang sangat baik (BSB) ada di 3 aspek perkembangan yaitu menggambar sesuai gagasannya, menggunting sesuai pola dan menempel gambar dengan tepat. Setelah pelaksanaan kegiatan mewarnai menggunting dan menempel perkembangan motorik halus anak meningkat ini terlihat dari grafik ke dua, terlihat aspek perkembangan motorik halus anak yang berkembang sangat baik (BSB) meningkat di semua aspek perkembangan.

Untuk kegiatan mewarnai, mengunting dan menempel dari barang bekas sudah dilakukan oleh sekolah, sehingga guru tidak mengalami kesulitan saat kegiatan atau pun dalam mengumpulkan bahan atau media. Guru masih memiliki kesulitan untuk kegiatan mewarnai menggunting dan menempel dengan kontruksi 3 dimensi. Untuk mengatasi hambatan tersebut guru mencari sumber atau ide melalui media elektronik yaitu hp, serta bertanya pada sesama guru PAUD. Aplikasi yang digunakan untuk mencari ide atau sumber adalah aplikasi facebook. Jika melalui media elektronik dan bertanya ke sesama guru belum menemukan ide yang dicari maka guru akan mencoba mengutak-ngatik barang bekas agar menjadi media konstruksi 3 dimensi. Untuk menambah ide dan pengetahuan guru memanfaatkan teknologi yaitu dengan menggunakan smartphone, dengan smartphone ini guru mencari informasi yang berkaitan dengan kegiatan mewarnai menggunting dan menempel dengan knstruksi 3 dimensi, aplikasi yang digunakan adalah facebook. Kegiatan sekolah yang dilakukan jarak jauh atau belajar dari rumah menuntut guru agar lebih inovatif menyampaikan kegiatan pembelajaran dengan bantuan orang tua tentunya.

\section{Kesimpulan}

Berdasarkan hasil penelitian dan pembahasan yang sudah dilakukan peneliti menyimpulkan kegiatan mewarnai menggunting dan menempel dengan menggunakan barang bekas bentuk 3 dimensi mempengaruhi peningkatan perkembangan motorik halus anak. Terlihat dari aspek-aspek perkembangan motorik halus anak yang meningkat setelah kegiatan. Sebelum kegiatan perkembangan motorik halus anak yang berkembang sangat baik hanya di 3 aspek perkembangan yaitu menggambar sesuai gagasannya, menggunting sesuai pola dan menempel gambar dengan tepat, setelah dilaksanakan perkembangan motorik halus anak yang berkembang sangat baik ada di semua aspek perkembangan motorik halus yaitu menggambar sesuai 
gagasannya, meniru bentuk, melakukan eksplorasi dengan berbagai media dan kegiatan, menggunakan alat tulis dan alat makan dengan benar, menggunting sesuai dengan pola, menempel gambar dengan tepat, mengekspresikan diri melalui gerakan dan menggambar secara rinci.

Perencanaan pembelajaran di pos PAUD sudah baik, guru membuat RPPM dan RPPH dengan menggunakan STPPA sesuai kurikulum 2013. Didalam RPPM sudah mencatumkan identitas program, tujuan pembelajaran, materi pelajaran yang disesuaikan dengan tema pembelajaran. Dalam RPPH di dalamnya terdapat identitas program, tujuan pembelajaran, materi pembelajaran, sumber belajar, metode pembelajaran, alat dan bahan yang digunakan.

Guru menggunakan barang-barang bekas untuk kegiatan pembelajaran dan juga barang baru, sehingga dapat mengurangi biaya. Barang bekas ini diperoleh dari guru, orang tua murid dan tetangga. Kegiatan yang menghasilkan konstruksi 3 dimensi sudah terlihat di beberapa hasil karya anak, namun belum terlalu banyak. Untuk ide kegiatan pembelajaran dengan konstruksi 3 dimensi guru lakukan dengan diskusi sesama guru dan menggunakan media sosial yaitu menggunakan facebook untuk mencari ide-ide.

\section{Daftar Pustaka}

[1] Anwar, Citra Rosalyn. dkk. (2018). Kolase Barang Bekas untuk Kreativitas Anak (Taman Kanak-kanak Nurul Taqwa Makassar). Jurnal Ilmu Pendidikan, Keguruan, dan Pembelajaran Volume 2 Nomor 1

[2] Aqib, Zainal (2017) Penelitian Tindakan Kelas. Yogyakarta: Ar-Ruzz Media

[3] Ariesta, Riany. (2009). Pengenalan Seni Rupa untuk anak usia 2-6 tahun. Jakarta: PT Albama

[4] Ayuni, Despa. Dkk. Kesiapan Guru TK Menghadapi PEmbelajaran Daring Masa Pandemi Covid-19. https://www.obsesi.or.id/index.php/obsesi/article/view/579/pdf

[5] Erhamwilda. Afriyanti, Nurul. (2014) Bahan Ajar Psikologi Perkembangan. Bandung: Universitas Islam Bandung.

[6] Hurlock, Elizabeth B. (2016) Psikologi Perkembangan. Jakarta: Erlangga.

[7] Indaswari, Lolita. Peningkatan Perkembangan Motorik Halus Anak Usia Dini Melalaui Kegiatan Mozaik Di Taman Kanak-Kanak Pembina Agam. Jurnal Pesona PAUD Vol.1.No.1. http://103.216.87.80/index.php/paud/article/viewFile/1633/1407

[8] Khodijah, Nyayu. (2016) Psikologi Pendidikan. Jakarta: Raja Grafindo Persada.

[9] Maryani, Kristiana. Penilaian dan Pelaporan Perkembangan Anak Saat Pembelajaran di $\begin{array}{llll}\text { Rumah di } & \text { Masa }\end{array}$ https://murhum.ppjpaud.org/index.php/murhum/article/view/4

[10] Masnipal (2015). Dasar-Dasar Pendidikan Anak Usia Dini. Bandung: Universitas Islam Bandung.

[11] Masnipal.(2018). Menjadi Guru PAUD Profesional. Bandung: Rosda.

[12] Mendikbud. Peraturan Menteri Pendidikan dan Kebudayaan Republik Indonesia nomor 137 tahun 2014

[13] Murtining, harti. (2018). Meningkatkan motorik halus melalui kegiatan menggunting dengan berbagai media pada Kelompok B TH Dharma wanita Tawangrejo http://ejournal.unipma.ac.id/index.php/JPAUD/article/view/3094/1787

[14] Musfiroh, Tadkiroatun (2017) Pengembangan Kecerdasan Majemuk. Tangerang: Universitas Terbuka.

[15] Nurul Arifa, Fieka. Tantangan Pelaksaan Kebijakan Belajar Dari Rumah Dalam Masa Darurat COVID-19. https://d1wqtxts1xzle7.cloudfront.net/63907108/Info_Singkat-XII7-I-P3DI-April-2020-195320200713-23390-cke2hn.pdf?

[16] Pamadhi, Hajar. Sukardi S, Evan (2012). Seni Keterampilan Anak. Banten: Universitas Terbuka.

[17] Rachmawati, Yeni. Kurniati, Euis (2017). Strategi Pengembangan Kreativitas Pada Anak. 
Jakarta: Kencana

[18] Ratreni, Ni Luh. Dkk. Penerapan Pemberian tugas dan kegiatan 3M untuk meningkatkan perkembangan motorik halus anak kelompok B TK Widya Kumara Sari Tunjung https://ejournal.undiksha.ac.id/index.php/JJPAUD/article/viewFile/1082/946

[19] Resty, Polina. Dkk. Analisis Peran Guru Dalam Menstimulasi Motorik Halus Anak Di TK Aisyiyah Bustanul http://jurnal.untan.ac.id/index.php/jpdpb/article/view/17429

[20] Rohendi, Aep. Seba, Laurens (2017). Perkembangan Motorik. Bandung: Alfabeta

[21] Sujiono, Bambang. Dkk. (2014). Metode Pengembangan Fisik. Banten: Universitas Terbuka.

[22] Sugiyono. (2018). Metode penelitian Pendidikan. Bandung: Alfabeta.

[23] Surat Edaran Menteri Pendidikan dan Kebudayaan Nomor 4 Tahun 2020 ini mengatur tentang Pelaksanaan Kebijakan Pendidikan Dalam Masa Darurat Penyebaran Covid-19

[24] Wali Kota Bandung, Peraturan Wali Kota Bandung nomor 18 Tahun 2020.

[25] Wijoyo, Hadion. Dkk. Model Pembelajaran Menyongsong New Era Normal Pada Lembaga PAUD DI RIAU. https://jurnal.unimed.ac.id/2012/index.php/js/article/view/18526 